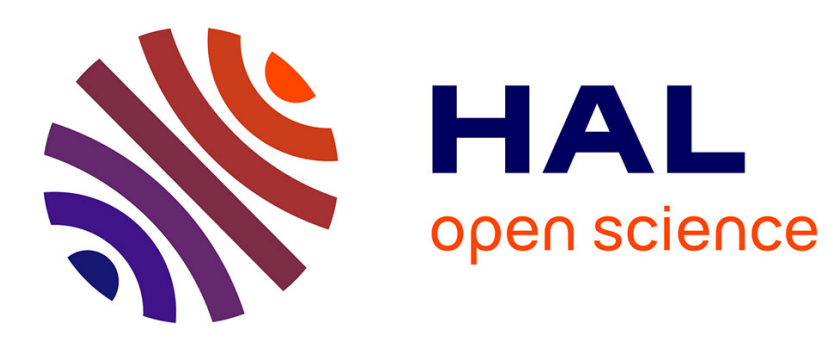

\title{
The European Parliament and Covid-19. Organisational adaptations and their implications on parliamentary activity
}

Nathalie Brack, Olivier Costa, Awenig Marié

\section{- To cite this version:}

Nathalie Brack, Olivier Costa, Awenig Marié. The European Parliament and Covid-19. Organisational adaptations and their implications on parliamentary activity. Zeitschrift für Parlamentsfragen (ZParl), 2021, 4, pp.848-863. 10.5771/0340-1758-2021-848 . halshs-03500996

\section{HAL Id: halshs-03500996 \\ https://shs.hal.science/halshs-03500996}

Submitted on 22 Dec 2021

HAL is a multi-disciplinary open access archive for the deposit and dissemination of scientific research documents, whether they are published or not. The documents may come from teaching and research institutions in France or abroad, or from public or private research centers.
L'archive ouverte pluridisciplinaire HAL, est destinée au dépôt et à la diffusion de documents scientifiques de niveau recherche, publiés ou non, émanant des établissements d'enseignement et de recherche français ou étrangers, des laboratoires publics ou privés. 


\title{
The European Parliament and Covid-19. Organisational adaptations and their implications on parliamentary activity
}

\author{
Nathalie Brack, CEVIPOL, Université libre de Bruxelles \\ Olivier Costa, CNRS-CEVIPOF, Sciences Po, Paris \\ Awenig Marié, CEVIPOL/FNRS, Université libre de Bruxelles
}

Zeitschrift fuï Parlamentsfragen (ZParl), 4/2021, p. 848 - 863, 2021

DOI: $10.5771 / 0340-1758-2021-848$

Corresponding author: Olivier Costa - olivier.costa@,cnrs.fr

\begin{abstract}
As soon as March 2020, the President of the European Parliament (EP) has decided to shut-down the assembly's facilities in Brussels and to cancel the plenary sessions in Strasbourg. Important decisions were made to abandon in-person meetings, introduce teleworking for all staff, and implement remote deliberation and voting in both committees and the plenary. The Rules of Procedure were adapted to formalize these organisational changes in the eventuality of a new crisis. The EP proved to be resilient: it continued to discuss and adopt many legislative, budgetary, and non-legislative texts in plenary. However, the sequence of remote-work had an impact on the political dynamics within the EP. It was characterised by a very high level of consensus, as the result of a higher level of agreement between the two main groups, the EPP and S\&D. Also, the main groups became much more cohesive.
\end{abstract}




\section{Introduction}

The importance its members and leaders give to organisational issues has always been a particular feature of the European Parliament (EP). As an assembly originally deprived of competences, the institution needed to maximise every formal power it managed to get, reform after reform, in order to take advantage of the treaties' grey zones, and to make the most efficient use of its rights. This has always been very challenging, as the EP faces numerous constraints that are quite unique: it is composed of a very large number of members (705), elected in 27 countries; it operates with 24 official languages; members of the EP (MEPs) belong to more than 200 national political parties; and the EP has to cope with 3 different places of work - Brussels hosts the group and committee meetings, Strasbourg the 12 annual plenary sessions, and Luxembourg part of its administration. The EP also has to deal with a very substantial number of highly complex legislative texts and find the means to develop its own expertise on each topic. The assembly faces another challenge, that of overcoming a growing political fragmentation in order to find the majorities requested by the treaties and respect strict deadlines. Finally, the EP manages a very large staff; it employs around 8.000 civil servants and contract agents. All in all, with the accredited parliamentary assistants and MEPs, more than 10.000 persons work at the EP.

Despite the EP's long-standing focus on organization, the pandemic had a massive organisational impact on the European assembly. Indeed, the EP had never allowed its members to participate in any activity remotely. MEPs had always been called on to attend all meetings in person: even for votes in the plenary, it is strictly impossible for them to delegate their vote - as is possible or tolerated in some national chambers. Even staff members had always been required to be present: the possibility of working from home was extremely limited at the EP. Finally, the Rules of Procedure did not foresee a major crisis like Covid-19 nor did it anticipate the need to adapt the parliament's organisation in consequence.

For all these reasons, the President of the EP's March 2020 decision to shut-down the assembly's facilities in Brussels and to cancel the plenary sessions in Strasbourg deeply challenged the institution. The matter was not only organisational: it was also about the place and role of the EP in the European Union (EU) regime, in circumstances that immediately gave a very central role to the executive institutions - European Council and Commission (Wolff \& Ladi 2020). Indeed, the 
capacity of the EP to organize its work efficiently has always had a major impact on its influence vis-à-vis the other EU institutions. For instance, its control and scrutiny activities, and its role as a forum on EU and international affairs, are directly linked to its capacity to take initiatives (Costa 2001). Even in the field of law-making, the "ordinary legislative procedure" foresees that, if the $\mathrm{EP}$ is unable to vote on a text in the requested delay in second reading, the so-called "Common position" of the Council becomes the law without the assembly's approval. Its influence is also very much linked to its ability to make the most of the treaties' grey zones, negotiate interinstitutional agreements in the margins of the treaties (Wiesner, 2018; Closa and al. 2021), and create a balance of power with the other institutions. In sum, the real challenge for the assembly was not only to find a way to organize its activities despite Covid-19, but to safeguard its position within the EU political system.

We will use a twofold approach to analyse how the EP coped with the pandemic and what the consequences were on its internal dynamics. First, we will describe the way in which the EP has managed the Covid-19 pandemic and adapted its mode of operations. Second, we will study the impacts of the pandemic and the EP's organisational adjustments on the political situation within the house, with a particular focus on the voting dynamics in the plenary.

\section{Adapting the European Parliament's organization to the pandemic}

The EP reacted quickly to the challenges of Covid-19. It took emergency measures in early March 2020, even before the World Health Organisation (WHO) declared the crisis to be a pandemic (11 March 2020). ${ }^{1}$ The main decisions were to call on all the members and the staff to stay home, cancel the plenary session in Strasbourg, and set up various systems that would allow remote voting and deliberation - in group, committees and plenary.

The most immediate measures were taken by the leadership organs of the EP: the President, the Bureau, the Quaestors, the Conference of Presidents (which comprises the President of the EP as well as the Chairs of all political groups) and the Conference of Committee Chairs. Later in 2020,

\footnotetext{
1 'WHO Director-General's opening remarks at the media briefing on COVID-19 - 11 March 2020', 11 March 2020, available at: https://www.who.int/director-general/speeches/detail/who-director-general-s-opening-remarks-at-themedia-briefing-on-covid-19---11-march-2020
} 
the EP amended its Rules of Procedure, so as to provide a solid legal basis for the changes that had taken place, and to have the necessary tools at its disposal in the event of another similar crisis. Rules of Procedure have always played a major role in the overall organization of the parliament. They are extremely detailed and codify all aspects of the EP's functioning and deliberation. The Rules are amended very often in order to reflect any evolutions in the EU's institutional context, especially constitutional changes, and to support the EP's strategy of empowerment (Brack and Costa, 2018). In the case of the Covid-19 pandemic, the strategy was the same: the EP needed to adapt its internal operations to the pandemic, but also to remain fully involved in the functioning of the EU. This was fundamental in order to avoid leaving free reins to the Commission and the European Council, and thus changing the institutional balance of the entire EU political system.

This section will study how the EP adapted its modes of operation to the Covid-19. We will first present the different measures taken by the institution. Secondly, we will turn our attention to the development of a whole new system of remote voting in both the EP plenary and its committees. Thirdly, we will present the amendments to the Rules of Procedure. The last section will discuss these changes, why they were possible, and what impacts they may have on the EP.

\section{a. Urgent measures taken by the leadership organs}

The main challenge for the President, the Bureau, and the Quaestors was to find a path between the necessity to protect members and staff from Covid-19, and the dual imperatives of respecting their rights and the functional capacities of the EP. Sanitary risks were especially high in the EP, compared to other chambers, because of the constant travel of its members between their constituencies, Brussels, and Strasbourg. Soon, they would also face lock-downs and travel restrictions within and between European countries.

The first decisions were taken by the President of the EP on 2, 5, and 9 March 2020, following advice by the EP medical team (Richard-Molard 2021). As there were no provisions in the Rules of Procedure pertaining to a potential situation of emergency, the President took its decisions on the grounds of article 22-5, stating that "the President is responsible for the security and the inviolability of the premises of the European Parliament'. He notably decided to suspend the plenary sessions that were planned in Strasbourg, against treaty provisions. His decisions were approved by the Conference of Presidents, representing all political forces in the EP, and were reiterated several times in 2020 and 2021. 
The President also decided to limit access to the EP facilities and restrict travel to and from highly contaminated regions. He asked the Secretary General to organize the functioning of the EP and its organs via digital tools. The goal was to replace all physical meetings with IT solutions. This involved using various communication tools, generalizing video conferencing and developing systems for the real-time interpretation of online meetings. The EP's IT service was also in charge of developing procedures and tools that would allow remote and hybrid voting (decision of the Bureau, 20 March 2020).

The Secretary General soon decided to organise teleworking, at first for vulnerable staff members (9 March 2020) and then for nearly all personnel (21 April 2020). Agents were equipped with 'hybrid' computers, allowing them to use the EP's interface from home. They were granted access to communication software like Webex, Jabber, and Microsoft Teams, as well as to an in-house video conferencing system. For member meetings, the EP developed a system of remote interpretation in several languages (Ripoll Servent and De Feo, forth.). As early as 23 March 2020, Interactio, a Lithuanian start-up, delivered a system that was capable of organising multilingual virtual meetings. However, the tool's availability was limited and the unavailability of interpreters restricted the number of languages offered. Indeed, travel restrictions prevented many interpreters from accessing the EP premises in Brussels where the interpretation was organized. The assembly explored various solutions; the interpretation facilities in Strasbourg were mobilized, as well as a number of "hubs" across the EU. Ultimately, technical solutions were found to allow interpreters to work from home (Ripoll Servent and De Feo, forth.).

The Bureau and the Quaestors decided to mandate the use of sanitary masks within the EP (8 May 2020), test the body temperature of people entering the premises (15 June 2020), and create a testing centre within the parliament. Most of those decisions remained in force until the end of March 2021.

The President confirmed his decision to suspend travel to Strasbourg for the plenary sessions: from March 2020, they were organized in Brussels, in a hybrid form. After a couple months, the French authorities complained that the repeated decision to organize plenary meetings in Brussels breached the treaties. Indeed, twelve periods of monthly plenary sessions must be organised each year in Strasbourg (art. 1 of protocol 6). Any change would require the "common accord of the governments of the Member States" (art. 341 TFEU). This was not the first time that the EP had supposedly breached the protocol on the location of the seats of the institutions. However, as the EU Court of Justice considered, the protocol and the other provisions regarding the role of the EP in the budgetary or legislative procedures hold the same legal value and, therefore, the EP 
could legitimately contravene to the protocol in order to adopt acts within the period prescribed by the treaties ${ }^{2}$ The French authorities, along with the Mayor of Strasbourg, further claimed that the sessions could be organized in Strasbourg with a decent level of safety. Official diplomatic complaints were followed by a letter from the French President (23 September 2020). ${ }^{3}$

In July 2020, the Bureau of the EP discussed potential solutions to once again convene plenary sessions in Strasbourg, but the difficulties and potential risks seemed too significant. Additionally, it was easier to hold them in Brussels, even in a hybrid form. While most MEPs' main residence is in their constituency, at least 100 live in the Brussels area with their families. This is also the case of most other actors of the EP: agents of the EP general secretariat and of the political groups, parliamentary assistants, contract agents, etc. The development of IT tools allowing MEPs to participate in meetings remotely, with the possibility of an interpretation, and technical solutions making it possible for them to vote from remote locations also made returning to regular plenaries less urgent. The second wave of Covid-19, in the fall of 2020, convinced David Sassoli, the President of the EP, to prolong all the measures regarding remote work and deliberation (29 October 2020). The presence of members on EP premises was even more limited than during the first lockdown, with the exception of a few trilogue meetings.

The EP finally returned to Strasbourg in June 2021, after more than one year of absence. However, the session was still organized in a hybrid format, with most MEPs participating online. This time, it was anti-Strasbourg members (a loose alliance of members generally in favour of a single seat in Brussels, joined by members worried about travelling in times of a pandemic) who protested, claiming that a large number of parliamentary assistants were forced to travel without being vaccinated, and that the rules applying to cross-border trips were too constraining (Covid test to enter France and compulsory quarantine on the way back to Brussels).

\section{b. Remote voting in plenary sessions and parliamentary committees}

At the very beginning of the pandemic, votes were organized via email, whether MEPs were present on site or not. This system was quickly implemented in order to adopt the first texts dealing

\footnotetext{
${ }^{2}$ Case C-92/18, French Republic vs. European Parliament, 2020. :

${ }^{3}$ Présidence de la République française, « lettre du Président de la République adressée à M. David Sassoli, Président du Parlement européen », 23 September 2020, available online: https://www.elysee.fr/emmanuelmacron/2020/09/28/lettre-du-president-de-la-republique-adressee-a-m-david-sassoli-president-du-parlementeuropeen
} 
with the Covid-19 crisis during the March 2020 plenary session. For each text, every member received a full voting list to be completed and sent back by email to the secretariat of the committee. Later, a specific portal was created, allowing MEPs to download and fill in the list of votes. In plenary meetings, MEPs were called on to vote not on a single text, but on a set of texts, as they usually do during the "voting hours". They had to vote on the amendments first, and the final text second. A specific app called "ivote", based on the Apple iOS, was developed, allowing MEPs to vote directly from a digital device. This was challenged by some members, especially those from left-wing political groups (Ripoll and De Feo, forth.) since it forced MEPs to use an Apple device. Consequently, DG ITEC developed a new app based on the same language as ivote but within the EP's interface (Ripoll and De Feo, forth.). It was then approved by the Committee on Constitutional Affairs (AFCO) and the plenary during the reform of the Rules of Procedure (see below).

Similar measures to the ones adopted for the plenary sessions were also implemented for the parliamentary committee meetings. Within the EP, most of the work is organized at that level, be it for legislation, initiatives, or budget matters. Practically, because of the specific constraints that weigh on the EP as a supranational assembly (interpretation in 24 languages, large number of members, rigid calendar of sessions...), the plenary is mainly there to vote on texts and decisions that are already fully negotiated in the committees. The Conference of Committee Chairs was in charge of defining the practical arrangements for committees, especially regarding voting procedures. A document was adopted on 8 April 2020, in line with the Bureau's decisions. It contained a series of guidelines and recommendations. Overall, the idea was to replicate at the committee level the rules applying to the plenary session in times of exceptional circumstances. Specific decisions were also made regarding the participation of deputy-members in the votes, checking the quorums, and drawing-up voting lists (see Richard-Molard, 2021, p. 5).

Overall, the remote voting system gave MEPs more freedom regarding their votes. Usually, when sitting in committee or in plenary, members get written voting instructions before the meeting and may follow them if they want to show loyalty (Mühlböck \& Yordanova, 2017, 2012). These voting lists, which are subject to a democratic decision-process within the group, can also indicate that the vote is a "free vote". Additional instructions are given during the vote, in the form of visual indications (thumb up or thumb down) from the political group's coordinator or leader, or from the rapporteur or the group's shadow-rapporteur. The remote voting system allowed each MEP to potentially decide on his or her own voting position alone, especially for the most experienced legislators. This may have been more difficult for the very numerous newly elected members (the 
turnover was 60\% in May 2019), who did not really have the opportunity to discover how assembly operated before the outbreak of the Covid-19 pandemic, and may therefore have been more inclined to follow their group's instructions.

In plenary, remote votes were organized following the roll-call procedure: the results of individual votes on each amendment, article or text was systematically registered and made public - with the exception of a few "secret" ballots - while usually it is only the case of a third of votes. The situation in plenary was thus more constraining for MEPs than it was in committee, as their political groups could control each of their votes. Nevertheless, the context of remote voting and detachment from the groups may have encouraged members to draw-up their own voting lists and no longer rely on voting instructions. ${ }^{4}$

\section{c. The inclusion of "exceptional circumstances" in the Rules of Procedure}

In April 2020, on the heels of the first remote plenary session, the AFCO committee created a working group to brainstorm the necessary adaptations of the Rules of Procedure. At first, some members proposed amending the entire document, but the working group decided to draft an article specific to "exceptional circumstances" that would have an overall impact on the rules. The reform's objective was not only to provide solid legal ground for the new rules of functioning within the EP but also to endow the institution with a broad strategy to ensure its continuity of operations under "exceptional circumstances" which may prevent members from gathering or travelling (as had already been the case during the volcanic eruption of Eyjafjallajökull in Iceland in 2010). However, the reform was not designed to allow members to participate remotely for personal or medical reasons.

MEP Gabriele Bischoff (member of the S\&D group) was appointed rapporteur and presented her work to the AFCO committee on 10 July 2020. The report was voted on by the committee on 12 October $2020^{5}$, and by the plenary on 17 December $2020^{6}$. In this text, the EP first stressed that

\footnotetext{
${ }^{4}$ On remote voting and its assessment, see Andrea Circolo, 'The remote voting between force majeure and procedural guarantees: EP's leading initiative and other national examples. What changes and what remains', 2020, available at: http://rivista.eurojus.it/wp-content/uploads/pdf/Circolo.pdf

${ }^{5}$ Report on amendments to the Rules of Procedure in order to ensure the functioning of Parliament in extraordinary circumstances (2020/2098(REG)), Committee on Constitutional Affairs, Rapporteur: Gabriele Bischoff, A90194/2020, 16.10.2020.

${ }^{6}$ European Parliament, decision on amendments to the Rules of Procedure in order to ensure the functioning of Parliament in extraordinary circumstances (2020/2098(REG)), P9_TA(2020)0380, 17.12.2020.
} 
the temporary measures decided by the President and other leadership organs were "fully justified" and that all the votes taken during that time were valid. The report then created 4 new articles (237a, b, c and d).

Article 237 a allows the EP to take "extraordinary measures" to continue to carry out its duties in exceptional circumstances. It is up to the President to determine that, "for reasons of security, or safety or as a result of the non-availability of technical means it is, or will be, impossible or dangerous for Parliament to convene in accordance with its usual procedures". It then allows the President, following certain procedures, to implement one or more of the measures foreseen:

- postponement or cancellation of a scheduled part-session, sitting or meeting of a committee, inter-parliamentary delegation or other body;

- displacement of those to another place;

- use of separate meeting rooms for a plenary session;

- organization of meetings in remote;

- temporary replacement of Members in a committee by political groups ${ }^{7}$.

All those decisions must be justified and limited in time and should be applied only as a last resort. Members or a political group can ask for the plenary to approve them.

Rule 237b allows the President to adopt measures to facilitate the participation of members of a given group if the political balance is severely impaired because a significant number of them cannot take part in the EP's proceedings for reasons of security or safety, or as a result of the nonavailability of technical means. They can then participate remotely.

Rule 237c establishes the remote participation regime. It insists on the right for MEPs to speak in plenary and in the committees, to vote, and to table texts. It also allows the President to determine how to adapt the rights and practices which cannot be exercised without the physical presence (quorum, tabling of texts or amendments, allocation of speaking time, ordering of votes, etc.).

Finally, rule $237 \mathrm{~d}$ explains how a part-session or a plenary sitting can be organised in separate meeting rooms, to respect physical distancing requirements.

\footnotetext{
7 In non-extraordinary time, if the full member of a committee cannot attend and heir substitute is absent, the full member appoints another member of the same political group to represent hem (art. 209-7). In extraordinary times as covered by the new rules, political groups appoint the substitute in case the full member and their substitute are absent.
} 
Overall, the reform is largely inspired by the experience of the Covid-19 pandemic and by the solutions that allowed members to participate remotely. More generally, it empowers the President of the EP, which is consistent with previous reforms of the rules (Brack and Costa 2018).

\section{d. Towards an even more "rationalized" deliberation?}

With the Covid-19 pandemic, the EP has proven its capacity to adapt swiftly to unforeseen events. This was only possible because of the central and powerful role of the EP's leadership bodies (the Presidency and the Bureau), and the long tradition of "rationalizing" the EP activities. This sequence of events has contributed to further increase the competences and influence of those organs, in line with an evolution that goes back to the late 1980s (Brack and Costa, 2018). This process of adaptation was also facilitated by the consensus existing between the main political groups, and by the key-role given to the Conference of Presidents - which they dominate - in the reorganization of EP deliberation. The situation of "co-management" of the EP by the three main groups (EPP, S\&D, and Renew) made a quick reaction possible, despite the reluctance expressed by smaller groups and some individual members.

Three other factors were at play here. First, the true nature of the EP, a relatively young institution in constant evolution, that is more committed to its overall efficiency and influence in the EU political system than to respecting institutional traditions. Second, the fact that the EP's members are elected in 27 countries across Europe certainly made it easier for them to accept the idea of a fully online deliberation, as the international travel restrictions, the drastic reduction in flight availability, and the various sanitary measures would have made it impossible for them to attend the meetings in person (Rozenberg 2020). Finally, the EP benefited from the importance of IT services and solutions in its regular organization, and by the priority given by the President and the General Secretary to digital innovations long before the outbreak of the pandemic.

One should also note how efficient the EP has been in making quick organisational adjustments. The Rules of Procedure now include detailed provisions on how to face "exceptional circumstances", including rules for organising remote participation, deliberation, and voting, and offer guarantees against any unnecessary use of those rules. Although some members may have appreciated the opportunity to exercise their mandate remotely, and even if IT services developed various efficient tools to this end, all observers agree that the political dynamics of the EP have been impacted by those adaptations, and that MEPs' participation in the deliberation has been 
impaired (Ripoll Servent and De Feo, forth). This is why the AFCO committee has proposed to limit the use of remote functioning to what is strictly necessary.

\section{The impact of Covid-19 on voting and coalition patterns in the EP}

This section will analyse the impact of the Covid-19 pandemic on voting and coalition patterns in the EP. As no political group has ever had an absolute majority in the EP, reaching a compromise and building coalitions is an important and necessary step in order to pass laws and adopt resolutions. The analysis in this section relies on a dataset containing all roll-call votes (RCVs) from the beginning of the 9th legislative term (July 2019) until February 2021. This tallies around 6,400 votes. The data has been extracted from the EP's Public Register of Documents ${ }^{8}$. Additional information regarding the type of vote (whether it is a vote on a final text or not) and the procedure (legislative, budgetary, or non-legislative) has been extracted from the Legislative Observatory website 9 . Finally, in order to investigate the specificities of votes on Covid-related texts, we determined which procedure files are related to the EU's response to the pandemic based on the list provided on the website of the Legislative Observatory ${ }^{10}$. The use of RCVs is quite common in the study of legislatures around the world, including the EP (e.g. Attinà, 1990; Hix et al., 2005; Høyland, 2010; Roger et al., 2017). It has been criticized (Carruba et al., 2006), but it provides a useful indication of the political dynamics, especially if we consider their variations across time.

The impact of the pandemic on voting in the parliament may be twofold. First, we expect consensus and coalition-building patterns to be different for texts related to the EU's response to the pandemic than for those not related to it. Secondly, the Covid-19 crisis, and its consequences in terms of work organisation in the parliament, may have affected the way MEPs and political groups vote and build coalitions in the long run, regardless of the content (Covid-19 related or

\footnotetext{
8 Available at: https://www.europarl.europa.eu/RegistreWeb/search/simpleSearchHome.htm

${ }_{9}^{9}$ Available at: https://oeil.secure.europarl.europa.eu/oeil/home/home.do

10 The procedure files are those listed on this webpage:

https: / / oeil.secure.europarl.europa.eu/oeil/popups/thematicnote. $d o ? i d=2065000 \& l=e n$
} 
not) of the file under discussion. These two expectations will be tested in the following two sections.

\section{a. Consensus and conflict when the EP plenary votes on Covid}

EU countries faced an unprecedented crisis in March 2020 with the outbreak of the pandemic. Although they did not deliver a clear and coordinated response in the very early days, the EU institutions progressively seized on the issue and put forward measures aimed at addressing the crisis and its sanitary, economic, and social consequences.

The role of the EP in the EU political system is somewhat secondary - for instance, it does not have the right of legislative initiative - but still considerable. It can amend and has to approve the proposals initiated by the European Commission in budgetary matters and in most legislation. Out of the 53 Covid-related reports discussed and adopted by the EP plenary in the timeframe of our study (July 2019 - February 2021), more than half (28) were adopted under the rules of the "ordinary legislative procedure". For instance, in March 2020, when the President decided to cancel the plenary in Strasbourg, legislators were still requested to adopt three pieces of legislation that dealt with the pandemic. ${ }^{11}$ Around $11 \%$ of Covid-related texts adopted by the EP plenary were budgetary adjustments and emergency measures. Finally, $8 \%$ of Covid-related texts concerned taxation measures in relation to the Covid-19 pandemic and, as stipulated by the treaty provisions, were adopted by the EP under the "consultation" procedure - which drastically limits its influence.

In addition to the role the EP played in voting the legislation initiated by the Commission, it also adopted non-legislative reports. Although it has had a limited role during the crisis compared to that of European executives, the EP has not remained quiet and has used its "tribunitian power" to state a position on the crisis and its consequences. Between the outbreak of the pandemic and February 2021, the EP drafted and adopted two initiative reports, one on the gender implications of the crisis (2020/2121(INI)) and one on its consequences on foreign policy (2020/2111(INI)). Moreover, around $21 \%$ of Covid-related texts adopted during the timeframe of our study were non-legislative resolutions. According to Braghiroli (2021), one of these, the resolution on "EU coordinated action to combat the COVID 19 pandemic and its consequences" (2020/2616(RSP)),

\footnotetext{
11 "Specific measures to mobilise investments in the health care systems of the Member States and in other sectors of their economies in response to the COVID19 outbreak", 2020/0043(COD); "Financial assistance to Member States and countries negotiating their accession to the Union that are seriously affected by a major public health emergency", 2020/0044(COD); and "Allocation of slots at Community airports", 2020/0042(COD).
} 
already adopted in April 2020, very much influenced the subsequent Recovery plan for Europe proposed by the Commission in May 2020.

The organizational adaptations described in the first section of this paper thus allowed the EP to draft, discuss, and adopt multiple texts related to the EU's response to the Covid-19 pandemic. However, were the patterns of cooperation and conflict on Covid-19 texts different from those on files not related to the crisis? We consider a crisis as an extraordinary and unexpected moment that creates uncertainty and may pose a threat to any organisation or political system. In the EU, crises, such as the 2008 financial and economic crisis or the 2014 migration crisis, are likely to change the attitudes and behaviours of political actors, the way institutions interact with one another, how policy decisions are made, as well as the general orientation of European integration (Dinan et al., 2017; Brack \& Gürkan, 2021; Schimmelfennig, 2018).

Regarding the impact of the Covid-19 crisis, we expect it to have affected the way Covid-related policy decisions were made in the EP. We expect the Covid-19 crisis to have created a momentum that suspends conflict between political groups when adopting texts dealing with the response to the pandemic. Therefore, decision-making on Covid-related texts is expected to be more consensual.

We use Attinà's (1990) agreement index (AI) to capture the overall level of cohesion in plenary, a measure that has been widely used by the literature on the EP (Hix et al., 2003; Høyland, 2010; Hix \& Noury, 2009). The index is equal to 100 when the EP votes as a bloc and to 0 when the EP plenary is equally divided between all three voting options ("yes", "no", and "abstention"). The average agreement index in our RCV dataset (July 2019-February 2021) is 62. The agreement index for votes solely on texts related to the Covid-19 crisis is 68 against 61 for votes not related to the pandemic. The EP was thus more cohesive when voting on texts related to the EU's response to the pandemic than on others.

Another way to investigate consensus is to study the frequency of the different coalition configurations. Coalition-building is important in the EP since no political group holds a majority of seats on its own. Therefore, groups have to cooperate in order to reach the majority required to adopt a legislative or a non-legislative text. The literature has found that coalitions come together on the basis of ideology and not nationality (Kreppel \& Tsebelis, 1999). Therefore, the dominant dimension of competition in the EP is the left-right one, with the pro-/anti-EU dimension as a secondary one (Hix, 2001). Despite the importance of the left-right cleavage in the EP, it is indeed 
a well-documented fact that a great number of texts are adopted by a grand coalition between most of the pro-EU and centrist groups (Hix \& Lord, 1997; Kreppel \& Tsebelis, 1999; Brack, 2013).

Because of the prominence of the "grand coalition" between the Christian Democrats (EPP) and the Socialists $(\mathrm{S} \& \mathrm{D})$ at the plenary stage, we analyse this element first. As political groups may have set aside disagreements in order to make quick and strong decisions regarding the Covid-19 crisis, we expect the level of cooperation between the two largest groups to be higher on texts related to the pandemic. We consider that the two groups have voted together if the plurality (relative majority) of MEPs from both groups voted the same way ("yes", "no", or "abstention"). On average, the two traditional groups voted together on $83.2 \%$ of Covid-19 texts, against $74.2 \%$ for texts not related to the pandemic. Table 1 shows the average cooperation rate between the two political groups for the different procedures: legislative, budgetary, and non-legislative. In all instances, the EPP and the S\&D groups, cooperated more often, on average, on votes dealing with the response to the pandemic than on other votes.

Table 1: Cooperation rate between EPP and S\&D by type of file for both Covid-19 votes and non-Covid-19 votes.

\begin{tabular}{|l|c|c|c|}
\hline & Covid-19 votes & Non-Covid-19 votes & Difference \\
\hline Legislative file (COD) & $83.9 \%$ & $77.6 \%$ & $+6,3$ \\
\hline Budgetary file (BUD) & $100 \%$ & $82.9 \%$ & $+17,1$ \\
\hline $\begin{array}{l}\text { Non-legislative file } \\
\text { (RSP/INI) }\end{array}$ & $81.7 \%$ & $73.9 \%$ & $+7,8$ \\
\hline
\end{tabular}

We also expect smaller political groups to join this EPP-S\&D cooperation more often, therefore forming oversized coalitions more frequently. In order to check that, we restrict our analysis to the votes where the two main groups voted together (table 2). 
Table 2: Percentage of Covid-19 and non-Covid-19 votes in which smaller political groups had the same position as the EPP-S\&D coalition.

\begin{tabular}{|l|c|c|c|}
\hline & Covid-19 votes & Non-Covid-19 votes & Difference \\
\hline $\begin{array}{l}\text { Renew Europe } \\
\text { (Renew) }\end{array}$ & $97.9 \%$ & $96.6 \%$ & +1.2 \\
\hline $\begin{array}{l}\text { Greens-European } \\
\text { Free Alliance } \\
\text { (Greens-EFA) }\end{array}$ & $81.6 \%$ & $79.7 \%$ & +1.9 \\
\hline $\begin{array}{l}\text { European } \\
\text { Conservatives and } \\
\text { Reformists (ECR) }\end{array}$ & $67.9 \%$ & $60.0 \%$ & +7.9 \\
\hline $\begin{array}{l}\text { The Left in the } \\
\text { European } \\
\text { Parliament (GUE- } \\
\text { NGL) }\end{array}$ & $70.5 \%$ & $66.7 \%$ & +3.8 \\
\hline $\begin{array}{l}\text { Identity and } \\
\text { Democracy (ID) }\end{array}$ & $43.9 \%$ & $36.9 \%$ & +7 \\
\hline
\end{tabular}

On average, smaller political groups took part in coalitions with the EPP and S\&D groups on Covid-19 votes slightly more often than on votes not related to the pandemic. However, these results need to be considered with caution. Indeed, when running a set of regression models controlling for the procedure and the type of the vote, we found that the differences in the legislative behaviour of smaller groups between Covid-19 and non-Covid-19 votes are not statistically significant, with the exception of the conservative ECR group. ${ }^{12}$

Finally, to draw a finer picture of consensus and conflict in the EP, we turned our attention to the level of cohesion within political groups. A large body of research on voting behaviour in the EP shows that political groups play a crucial role in building coalitions, have a high degree of organisational structuration and, as a consequence, display elevated levels of intra-group voting cohesion (Hix \& Noury, 2009). We expect higher levels of party cohesion on Covid-19 votes since individual legislators may have put aside former disagreements and political groups are likely to request that their members show solidarity and unity in the face of this crisis.

12 The full results of all the regression analyses in this paper are available upon request. 
Table 3 shows the average agreement index for each political group and for votes on Covid-related texts and others. With the exception of the Greens-EFA and the ID groups, the agreement index for all other political groups in the EP is higher on votes related to the pandemic. We complement these results by a set of regression analyses predicting the agreement index for each group and controlling for the procedure (legislative, non-legislative, budgetary) and for the type of the vote (final or not). They confirm our findings for the three centrist political groups: cohesion was significantly higher on Covid-19 votes for the EPP, the S\&D, and the Renew groups.

Table 3: Average agreement index for each political group on Covid-19 and non-Covid-19 votes

\begin{tabular}{|l|c|c|c|}
\hline & Covid-19 votes & Non-Covid-19 votes & Difference \\
\hline EPP & $93.4 \%$ & $90.4 \%$ & $+3.0 \%$ \\
\hline S\&D & $96.1 \%$ & $93.7 \%$ & $+2.4 \%$ \\
\hline Renew & $93.5 \%$ & $90.1 \%$ & $+3.4 \%$ \\
\hline Greens-EFA & $97.1 \%$ & $97.7 \%$ & $-0.6 \%$ \\
\hline ECR & $80.8 \%$ & $77.7 \%$ & $+3.1 \%$ \\
\hline GUE-NGL & $87.8 \%$ & $86.7 \%$ & $+1.1 \%$ \\
\hline ID & $66.6 \%$ & $66.3 \%$ & $+0.3 \%$ \\
\hline
\end{tabular}

To sum up, we found that after the outbreak of the pandemic there was a moment of unity and solidarity around measures tackling the consequences of the crisis. However, when looking more closely at the different coalition patterns, and at the voting behaviour of political groups, we found that higher cohesion in the parliament is mostly driven by a closer cooperation between the two main political groups, the EPP and S\&D, which did not bring smaller groups on board more regularly. Also, only the three centrist groups (EPP, S\&D and Renew) showed a higher level of unity when it came to voting on Covid-19 files. 
While we expected more consensus in the EP, we see instead the continuation of former patterns of consensual legislative behaviour at the ideological centre of the parliament. Since the beginning of the 9th legislative term, the two main groups (EPP and S\&D) no longer hold an absolute majority of the seats in the EP. This led to a growing level of cooperation between the EPP and S\&D, systematically supported by the liberal Renew group and, secondarily, by the Greens-EFA group. In our dataset, between the beginning of the 9th term and February 2021, 72.8\% of all votes in plenary were won by a grand coalition between the EPP, the S\&D, and the Renew groups; the figure is even higher $(95.7 \%)$ for final legislative reports. The parliamentary response to the pandemic has thus reinforced these trends.

\section{b. The impact of organisational adjustments on parliamentary activity}

The pandemic has forced parliaments across the world, including the EP, to adjust their ways of operating (Akirav et al., 2021). These organizational adjustments likely affected the behaviour of MEPs and political groups and, subsequently, coalition patterns in the plenary. For instance, individual legislators may have had difficulty coping with the organisational changes in the parliament or IT tools. Legislators uncomfortable with the English language were unable to get interpretation at the very beginning of the pandemic. Moreover, the cancellation of all in-person meetings deprived MEPs and their assistants of the informal chats and information sharing that are specific to any work environment. Also, organisational changes in the EP may have disconnected some MEPs, especially backbenchers and legislators not fully integrated in the EP decision-making process, from the secretariat of their political groups (Ripoll Servent and De Feo, forth.).

To study the impact of organisational changes on parliamentary activity in the EP, we first analyse the ability of the parliament to continue adopting legislative, budgetary, and non-legislative reports. Then, we study the way those organisational changes affected voting in the EP plenary in the months that followed the outbreak of the pandemic.

Figure 1 shows the number of texts adopted every month by the EP plenary, whether they relate to the EU's response to the pandemic or not. 


\section{Figure 1: Number of reports adopted every month by the EP plenary}

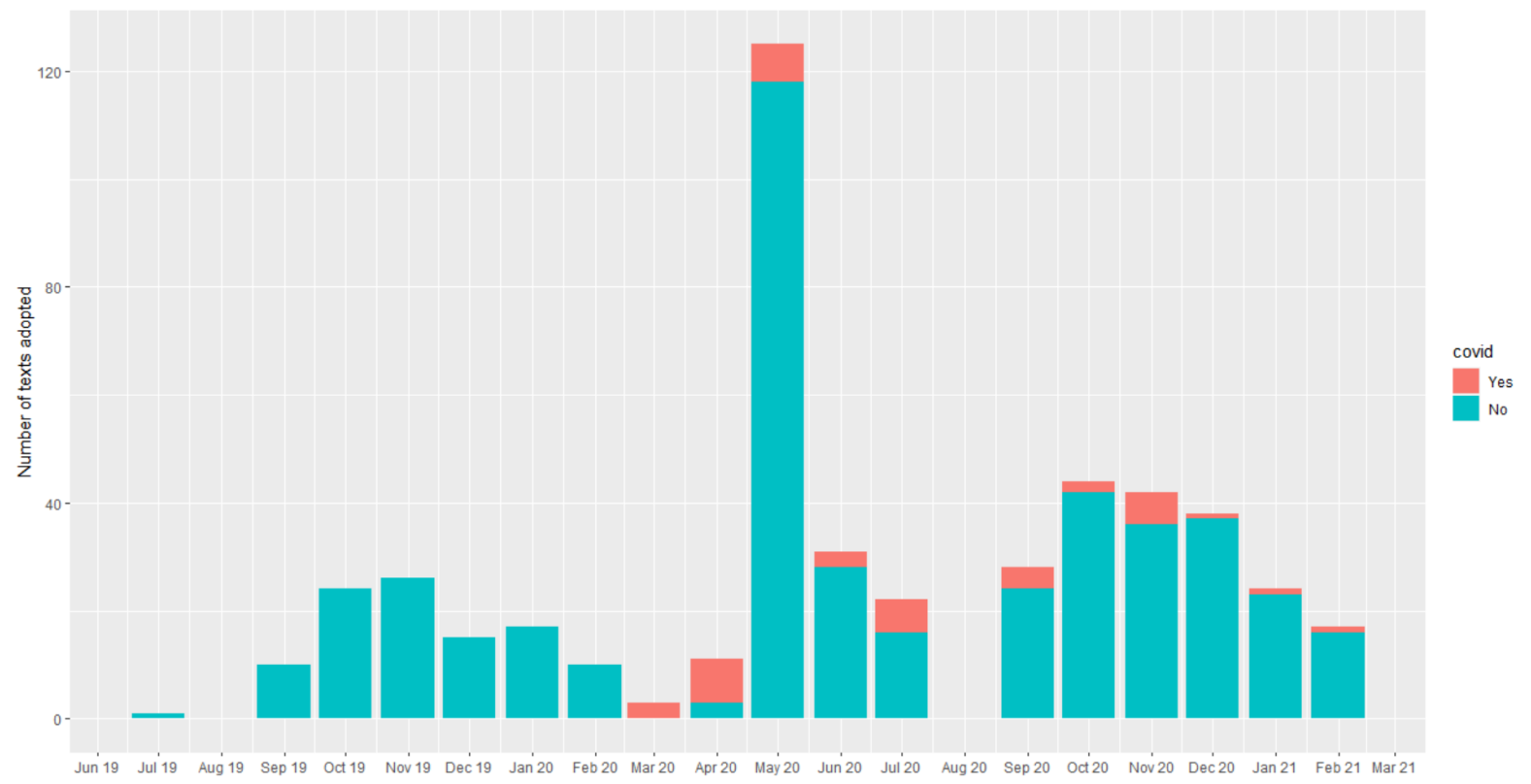

Our data shows that the Covid-19 pandemic did not affect the ability of the EP to discuss and vote reports. While the March 2020 session was entirely devoted to texts related to the pandemic, the EP returned to its usual business as early as May 2020. Furthermore, the peak in May 2020 confirms that the assembly managed to cope rather well with the pandemic and its organisational effects. The vast majority of reports adopted that month are discharges (DEC), and their attached resolutions, that are part of the procedure allowing the EP to scrutinise the way the Commission has implemented the EU budget.

The new organisational changes in the EP may also have had an impact on the legislative behaviour of individual MEPs and of political groups and, therefore, on coalition patterns. The organisational changes in the parliament (telework, remote deliberation, electronic voting) may have pushed individual MEPs - especially the $60 \%$ of them who were newly elected in 2019 - to rely much more on their political groups for their legislative activities. More specifically, with the new work constraints, we expect MEPs to have increasingly based their voting choice on the common position of their group, therefore decreasing the level of individual defection and, ultimately, increasing cohesion within political groups and in the parliament as a whole.

We first analyse the evolution of the overall level of agreement in the EP. Removing votes on texts related to Covid, did the level of cohesion within the plenary increase in the months that followed the outbreak of the pandemic? We ran a regression model predicting the level of agreement in the 
plenary and with the period of the vote as our main variable of interest. This period categorical variable can take on three different values depending on the date of the vote: before the outbreak of the pandemic (before March 2020), in the months that followed the outbreak of the pandemic (between March 2020 and August 2020), or after the summer recess (after August 2020). This regression analysis shows that, after controlling for the procedure (legislative, budgetary, or nonlegislative) as well as for the type of vote (final or not), the EP was more united when amending and adopting non-Covid-19 reports after the outbreak of the pandemic than before.

This evolution may be explained by two distinct trends, one related to an increase in the EPPS\&D voting cooperation and another to a lower level of defection among MEPs and, therefore, to higher levels of party cohesion. In order to distinguish those two effects, we first turn our attention to the evolution of the EPP-S\&D cooperation since the beginning of the 9th legislative term. Again, we remove votes related to the pandemic from the analysis. Overall, the two groups voted in the same way on $71.0 \%$ of reports before the outbreak of the pandemic, compared to 75.4\% between March and August 2020 and 74.6\% after the 2020 summer recess. Hence, it is clear that the EPP and the S\&D groups increased their cooperation after the outbreak of the pandemic, even on reports not related to Covid-19. This finding is supported by a regression analysis.

Second, we turn our attention to intra-group cohesion, which is also expected to have increased. We ran a set of regression analyses predicting the cohesion level within each group with the period of the vote as the main variable of interest. We find that the level of intra-party cohesion among the two main groups, the EPP and S\&D, significantly increased after the outbreak of the pandemic. It also improved - to a lesser extent - for the Greens-EFA, the Renew, and the ECR groups. By contrast, the two more radical groups, the GUE-NGL and the ID, were less cohesive after the outbreak of the pandemic than before.

These results suggest that the different political groups did not cope with the organisational consequences of the crisis in the same way. The organisation of the EPP and S\&D groups is indeed very structured and hierarchised and certainly continued to provide MEPs with information, expertise, and voting instructions. In a context of crisis, they have incentivised their members to be even more united and to show solidarity, even for votes not related to the pandemic. Although less structured, the Greens-EFA and Renew groups are also fully integrated in the coalitionbuilding process and were thus also concerned about the overall "efficiency" of the deliberation. By contrast, the GUE-NGL and ID groups, who often oppose the grand coalition, do not value cohesion as much; therefore, their individual members have been left more to their own devices in the months following the outbreak of the pandemic. 


\section{Conclusion}

In this paper, we first investigated the way the EP changed its methods of operation in order to adapt to the sanitary situation. Important decisions were made rapidly to cancel in-person meetings, introduce teleworking for all staff, and implement remote deliberation and voting in both committees and the plenary. The Rules of Procedure were adapted to formalize these organisational changes in the eventuality of a new crisis. The EP was capable of adapting swiftly to the Covid-19 crisis because of the central role played by its leadership bodies and thanks to the consensus among the main centrist groups (EPP, S\&D, and Renew). These changes were in line with a long-standing trend of reforms towards a rationalization of the EP's operations at the expense of its role as a public forum and of the individual rights of its members.

The second part of the paper analysed the way the Covid-19 pandemic, and the subsequent organisational adjustments in the EP, affected parliamentary activity and consensus at the plenary level. We first focused our attention on the legislative behaviour of parliamentary actors when discussing and adopting texts related to the EU's response to the pandemic. We found that they were characterised by a very high level of consensus, as the result of a higher level of agreement between the two main groups, the EPP and S\&D. We then turned our attention to the consequences of the organisational changes on parliamentary activity in the EP over the longer term. We found that the institution was resilient: it continued to discuss and adopt many legislative, budgetary, and non-legislative texts in plenary. However, the organisational adjustments have impacted the behaviour of individual MEPs and political groups. The groups at the heart of the decision-making process in the EP (EPP, S\&D, Renew, Greens-EFA) became much more cohesive after the pandemic, but this has not been the case for the others (GUE-NGL, ECR, ID).

Further work should focus on the individual level and should investigate how MEPs handled the organisational implications of the sanitary crisis. Indeed, while research on how the EP has coped with the pandemic remains scarce, the studies that do exist focus on the institutional level and on voting behaviour (Richard-Molard 2021; Braghiroli 2021; Rippoll Servent and de Feo, forth.). We still lack any analysis of how MEPs and the EP staff experienced the pandemic and the adaptation of the working methods of the EP, or of which variables impacted the way members adapted to the situation (age, seniority, political orientation, nationality...). Another avenue for future research is the impact of the pandemic on networks and on the contact between MEPs and a range of 
actors, from citizens to lobbies and civil society. While the pandemic made informal meetings and random encounters almost impossible, it also freed-up some time and opened up new possibilities for MEPs. It may have led to more frequent (online) meetings and contacts with specific groups such as voters but may also have led to a more restricted network of known contacts, making it more difficult for members to collect information and expertise from interest groups that they were not in contact with before. The impact of the pandemic on the individual work of MEPs, and on rapporteurs in particular, as well as the effect of individual-level variables would shed more light on how elected representatives at the EU level are affected by crisis situations.

\section{References}

Akirav, O., Coghill, K., Guasti, P., Haupt, P., Patzelt, W. J. \& Siefken, S. T. (2021). Parliaments in the Pandemic I. RCLS PiP Working Paper, 1, April 16.

Attinà, F. (1990). The Voting Behaviour of the European Parliament Members and the Problem of Europarties. European Journal of Political Research, 18(3), 557-79.

Brack, N. (2013). Euroscepticism at the supranational level: the case of the 'untidy right' in the European Parliament. Journal of Common Market Studies, 51(1), 85-104.

Brack, N., \& Costa, O. (2018). Democracy in Parliament vs. Democracy through Parliament? Defining the Rules of the Game in the European Parliament. The Journal of Legislative Studies, 24(1), $51-71$.

Brack, N., \& Gürkan, S. (2021). Introduction: European integration (theories) in crisis? In Theorising the Crises of the European Union. London: Routledge.

Braghiroli, S. (2021). The European Parliament put to the test by COVID-19: voting dynamics and coalition patterns of the EP's first response to the global pandemic, Journal of Contemporary European Studies, published online.

Carruba, C., J. , Gabel, M., Murrah, L., Clough, R., Montgomery, E., \& Schambach, R. (2006). Off the Record: Unrecorded Legislative Votes, Selection Bias and Roll-Call Vote Analysis. British Journal of Political Science, 36(4), 691-704. 
Closa, C., González de León, F., \& Hernández González, G. (2021). Pragmatism and the Limits to the European Parliament's Strategies for Self-Empowerment. Politics and Governance, 9(3), 163174.

Costa, O. (2001), Le Parlement européen, assemblée délibérante, Brussels, Éditions de l'Université de Bruxelles.

Dinan, D., Nugent, N. \& Paterson, W.E. (eds.) (2017). The European Union in Crisis. London: Palgrave.

Hix, S. (2001). Legislative Behaviour and Party Competition in the European Parliament: An Application of Nominate to the EU. Journal of Common Market Studies, 39(4), 663-688.

Hix, S., Kreppel, A. \& Noury. A. (2003). The Party System in the European Parliament: Collusive or Competitive. Journal of Common Market Studies, 41(2), 309-31.

Hix, S. \& Lord, C. (1997). Political Parties in the European Union. Basingstoke: Palgrave Macmillan.

Hix, S., Noury, A. \& Roland, G. (2005). Power to the parties: cohesion and competition in the European Parliament, 1979-2001. British Journal of Political Science, 35, 209-234.

Hix, S., \& Noury, A. (2009). After enlargement: voting patterns in the sixth European Parliament. Legislative Studies Quarterly, 34(2), 159-74.

Høyland, B. (2010). Procedural and party effects in European Parliament roll-call votes. European Union Politics, 11(4), 597-613.

Kreppel, A., \& Tsebelis, G. (1999). Coalition formation in the European parliament. Comparative Political Studies, 32(8), 933-966.

Mühlböck, M., \& Yordanova, N. (2017). When legislators choose not to decide: Abstentions in the European Parliament. European Union Politics, 18(2), 323-336.

Mühlböck, M., \& Yordanova, N. (2012). Party Group Cohesion in the European Parliament: Tracing the Bias in Roll-Call Votes. Available at SSRN: https://ssrn.com/abstract=2173785 or http://dx.doi.org/10.2139/ssrn.2173785

Richard-Molard Gabriel (2021), "The European Parliament in the COVID-19 crisis. A remote Parliament", Study, Robert Schuman Foundation, 8 p. 
Ripoll Servent, Ariadna and De Feo, Alfredo (forth.), "The European Parliament under COVID19: Institutional adaptation in times of pandemics", in O. Costa \& S. Van Hecke (ed.), Is Europe back in the driver's seat? The Union at a turning point in time, Palgrave.

Roger, L., Otjes, S., \& van der Veer, H. (2017). The financial crisis and the European Parliament: An analysis of the Two-Pack legislation. European Union Politics, 18(4), 560-580.

Rozenberg, O. (2020). Post Pandemic Legislatures. Is real democracy possible with virtual parliaments? (Discussion Paper No. 2). European Liberal Forum. https://hal.archivesouvertes.fr/hal-02934718

Schimmelfennig, F. (2018). European integration (theory) in times of crisis. A comparison of the euro and Schengen crises. Journal of European Public Policy, 25(7), 969-989.

Wiesner, C. (2018). The micro-politics of parliamentary powers: European parliament strategies for expanding its influence in the EU institutional system. Journal of European Integration, 40(4), 375391.

Wolff, S., \& Ladi, S. (2020). European Union Responses to the Covid-19 Pandemic: Adaptability in times of Permanent Emergency. Journal of European Integration, 42(8), 1025-1040. 